\title{
Juridical Implication of Otoritas Jasa Keuangan Authority in Banking Supervision in Indonesia
}

\author{
Ratnaningsih ${ }^{1}$ \\ Mohammad Khoidin ${ }^{2}$ \\ Dyah Ochtorina Susanti ${ }^{2}$ \\ ${ }^{1}$ Univesitas Lumajang \\ ${ }^{2}$ Universitas Jember
}

Doi: $10.2478 / m j s s-2018-0131$

\section{Abstract}

The law number 21 of 2011 on Otoritas Jasa Keuangan is the beginning of a new system implication on regulating and supervising the financial services sector in Indonesia. Initially, Indonesia implemented a model of supervision by several institutions to be an integrated supervision by single institution, i.e., Otoritas Jasa Keuangan. The application of Law of Otoritas Jasa Kauangan divides the authority of banking supervision into two ways, i.e., microprudential which is the authority of Otoritas Jasa Keuangan and macrprudential which is the authority of Bank Indonesia. The law does not give clear limits on the scope of the divisions, whereas both microprudetial and macroprudential are closely related. This division of authority may complicate Bank Indonesia to to carry out its duties as a central bank, therefore it need a synergy between Otoritas Jasa Keuangan and Bank Indonesia in Banking Supervision. This research aims at giving prescriptions on synergy model between Otoritas Jasa Keuangan and Bank Indonesia that can meet the principle of justice, legal certainty and expediency. The method used is normative juridical research by examining various laws and regulations and other literature studies. This research shows the needs of synchronization between the Law of Otoritas Jasa Keuangan and other related laws to omit overlaps of authority between Otoritas Jasa Keuangan and Bank Indonesia.

Keywords: Macroprudential, Microprudential, Supervision, Synergy, Synchronization

\section{Introduction}

Bank is an intermediary institution between depositors and the parties who need funds. Therefore public trust is important to maintain by the existence of banking supervisory institution. Initially, the regulation and supervision of Bank is the authority of Bank Indonesia, however by the prevailing of Law Number 21 of 2011 on Otoritas Jasa Keuangan (abbreviated as OJK), banking supervision is divided into two institutions having authorities. Based on the explanation of Article 7 of the Law of Otoritas Jasa Keuangan and the provisions of article 69, section 1 letter (a) of the Law on Otoritas Jasa Keuangan, affirms that Otoritas Jasa Keuangan concerns on the micproprudential, and Bank Indonesia concerns on the macroprudential in the monetary policies. Regarding the divisions between micropridential and macroprudential, the law does not give any clear explanations or limitations that may lead to overlaps of authority between OJK and Bank Indonesia. This research is significant because the existence of OJK damages Bank Indonesia to carry out the duties and authorities.

Banking supervision aimed at maintaining the trust of the public, especially of the depositors, that the bank is a reliable bank. Sulistyandari in her dissertation "Legal Protection of Depositors through Banking Supervision in Indonesia" (Sulistyandari, 2012) has not completely discussed 
banking supervision conducted by OJK because the law of Otoritas Jasa Keuangan has just been prevailed in the same year of the dissertation writing process. Thus, this article is based on the information stated in her dissertation. The prevail of the Law of Otoritas Jasa Keuangan requires further examination because there are fundamental changes related to banking supervision in Indonesia.

Based on Article 23 (D) of the 1945 Constitution of the Republic of Indonesia, it states that: "The state has a Central Bank whose structure, position and authority, responsibilities and independence are regulated by the Law." Furthermore, in Article 7 of Law Number 23 of 1999 on Bank Indonesia states that the objective of Bank Indonesia (abbreviated as $\mathrm{BI}$ ) is to achieve and maintain the stability of the value of Rupiah. As for achieving and maintaining the stability of the Rupiah, in Article 8 of Law No. 23 of 1999 on BI, BI establishes 3 (three) duties; determining and implementing monetary policy, regulating and maintaining the smoothness of the payment system flow, and regulating and supervising banks. Some of the authorities changing that previously owned by Bank Indonesia to OJK implicate on the legal certainty given to Bank Indonesia in performing its duties, therefore omitting some of Bl's duties in regulating and supervising banks may potentially complicate $\mathrm{BI}$ in achieving its objectives. Bank Indonesia as the central bank which is given the responsibility of creating the stability of the value of Rupiah will certainly find difficulties to fulfill its responsibilities if it does not have the authority to supervise the banks. The purpose of this study is to examine, analyze, and find the essence of banking supervision, and examine, analyze and find banking supervision model that reflects the synergy between $\mathrm{BI}$ and OJK that meets the legal certainty, justice and expediency.

\section{Literature Review}

\subsection{The Legal System Theory}

The legal system theory is used because banking supervisions is a legal system. The legal system theory used is the Legal System Theory of Kees Schuilt. According to Schuilt, a legal system consists of 3 elements that have certain independences that are interconnected, and each further can be elaborated. The elements that embody the legal system are: (Sidharta, 1999)

1. The element of idiil: this element is formed by the system of meaning of the law, which consists of rules and principles, this element is called the "legal system". Law science is certainly a science of meanings. Regarding to this article, the establishment of Otoritas Jasa Keuangan in implementing integrated regulation and supervision of the financial services sector in Indonesia, including banking is based on law no. 21 of 2011 on Otoritas Jasa Keuangan. Besides, it also examines the objectives and duties of $\mathrm{BI}$, so that the relevancies between the supervision of banks by OJK and the duties of $\mathrm{BI}$ in implementing the stability of the value of Rupiah can be obtained.

2. Operational Elements: This element consists of all organizations and institutions established in one legal system, which includes the functionalists within the framework of an organization or institution.

3. Actual Elements: This element is the whole concrete decisions and actions related to the system of meaning of the law, both from the functionalists and the public in which the legal system existed.

\subsection{The Theory of Justice (Ethical Theory)}

Aristotle opined Justice Theory is the law aimed at achieving justice among people. This theory is known as "Ethical Theory". Aristotle in his book "Ethica Nieo Macheis" and "Retorico" explained that the legal duty is to give justices for people. Johnny Ibrahim stated that the legal ideal to uphold justice is reflected in Fiat Justitia et pereat mundus or Fiat Justitia, ruat caelum. Both refer to an understanding that justice has to be upheld though the sky drops down. In other words, justice is upheld no matter risks are to take. Justice always contains elements of appreciation, assessment and judgment. Hence the mechanism of legal work is described as a balance of justice. Justice 
requires that under the same circumstances, everyone must receive the same part. In relation to justice, the law is compromising, because human justice is not absolute, considering that human being is imperfect creature, making mistake is a human nature (errare humanum est). The Natural law believes that justice is only from God the Almighty, but humans are also given the ability and capability to feel fairness. The natural law believes what is observed in all natural events around humankind has upheld justice (Ibrahim, 2005).

\subsection{The Legal Certainty Theory}

This theory is the analytical tool to reveal problems 1 and 2. Certainty cannot be separated from the law, especially for written legal norms. Nurhasan Ismail opines that the creation of Legal Certainty in the legislations require internal structures requirements of the legal norms. The internal requirements are: first, the clarity of concept used, legal norms contains the descriptions of certain behavior integrated to a certain concept. Second, the clarity of authority classes of the legislations. The clarity is important due to the validity of the regulations made. It leads the legislators to establish certain regulations. Third is the consistency of legal norms. It means that the provisions of laws and regulations related to a particular subject are not contradictive (Ismail, 2007).

\subsection{The Expediency Theory}

Jeremy Bentham opines that the ideal of law and justice is to achieve expediency that the Law is to guarantee the happiness of people. According to Bentham, the purpose of legislation is to create happiness for people or public ( Prasetya et.all, 2012).

\section{Methods}

This research belongs to juridical normative research since it examines and analyzes legal materials and issues. It reveals and resolves the problems occur, while the results provide prescriptions that should be taken (Marzuki, 2016). The approaches used in this research are as follows (Amiruddin, 2016):

1. Statue Approach is an approach to deeply analyze laws and regulations related to issues being handled.

2. Conceptual Approach is an approach that emits from currents views and doctrines in the legal science in order to obtain ideas that lead to definitions of law and principles of law or argumentations used by the researcher to handle the current legal issues.

3. Legal Historical Approach is an approach used to identify steps and factors that effects the legal development.

Law material collection method is the law and regulations studies that investigate and collect various regulations related to banking supervisions in Indonesia. Besides, literature studies are done to find concepts, theories, and opinions related to and relevant to the current legal issues discussed. The analysis of Legal Materials is done by identifying legal evidences and collecting legal materials that are relevant, analyzing proposed issues based on the materials collected, concluding and giving prescriptions based on the argumentations built in the conclusion. Regarding to these steps, inventory of positive law should be done first by organizing and exposing the legal material by describing the legal material in a systematic way that the essential and not essential elements should be separated and grouped based on certain characteristics. Second is to identify relevant legal sources. Third is processing principles of law, theory of law, concepts, doctrines and other literature studies to be systematic. Fourth is analyzing legal materials to find answers of the problems. The analysis used is the reasoning of law with deduction method that emerges from the existing law, and is analyzed to obtain comprehension that leads to a prescription. The last is drawing conclusion which is the generalization of the analysis on the Law of Otoritas Jasa Keuangan in relation with banking supervisions. The conclusion of the research is expected to contribute for future consideration and reference of the Law of banking supervisions. 


\section{Results and Discussions}

\subsection{Results}

Banking supervision is naturally as manifestation of thoughtfulness principles in organizing banks. This supervision is aimed at maintaining public reliance that the bank is reliable. It is important because banks rely on the depositors' savings. Supervision of Otoritas Jasa Keuangan on banking may lead to the unfulfilled of justice principles, legal certainty, and expediency especially for depositors because the divisions of microprudential supervision of Otoritas Jasa Keuangan and macroprudential of Bank Indonesia, whereas both supervisions are interrelated and should have synergy in supervising banks. It will be clearly explain in the following discussions.

\subsection{The Philosophical Meaning of Banking Supervision}

Banking industries play as central roles in the economic order of a state. If a county has good and reliable banking institutions, then the economic will grow strong. The existence of banks as intermediary institutions has been parts of the people daily life. The bank as financial intermediary is important in the transaction system and financial entity (Dewatripont ett all, 1994). As financial intermediary, bank collects funds of the public and distributes them to the public (Imaniyati, 2010). Reliance becomes the foundation of banks existence as intermediary institutions. Hence, it should be maintained by obeying the legal rules. Banking supervision should accurately observe the conditions of banking institutions in order that public reliance will be well maintained (Isnaeni, 2016). As stated in article 29 of Law Number 10 of 1998 on the Amendment of Law Number 7 of 1992 on Banking that Banks rely on the depositors funds on the basis of trust on the banks. The will of people to save their money at banks is urged by their trust that they will get their money on time or depends on the agreement of both parties. If the public reliance declines, rush will possibly happen, which means funds withdrawal by depositors (Hasanah , 2017).

The bank is closely related to currency in facilitating public financial activities. Thus, the functions of bank: as money lender that has the authority to keep and distribute publics funds effectively and efficiently (Djumhana, 2003). The integrity of financial institutions especially banks have important role in creating good financial system with several reasons including: the unique characteristic of banks that are susceptible to public bank runs which potentially inflict a financial loss upon the depositors and creditors. The financial loss spreads quickly through contagion effect that my cause system problems, the settlement of the problems need large amount of money, the loss of public reliance on banking sectors intermediary institutions may lead to financial distress. Financial sector instability will affect macroeconomic conditions especially that are related to ineffective monetary policy transmission. Bank runs of a bank may cause several banks to fail with national domino effect, it also damage the whole financial and economic systems (Kaufman, 1995). Banks failure is considered more destructive than other sectors. Large amount of public withdrawal may cause domino effects on the whole banking systems and will ruin both solvent and insolvent banks. In such condition, a bank's failure may affect on the whole systems failures or systematic risks. The systematic risk is dangerous because financial loss of one institution can spread and threaten other institutions (Cranston R, 1997). It can be seen from the high correlation between bank failures in one cluster of a county even in the whole world (Wijoyo, 2015). Therefore, the central banks and banking supervising institutions around the world concern on the systematic risks. It is due to the impact will surely damage the national economic condition (Kaufman, 1995). Loss of public reliance on banks as intermediary institutions causes financial distress.

To maintain the public trust, legal protection for customers or depositors is required. It can be done in two ways, those are: implicit deposit protection that emerges from effective banking supervision and founding, and explicit deposit protection through institution that guarantee customers' deposits. Thus if the banks fail, they will be responsible for returning customers' deposits. This protection is obtained from the establishment of institutions that warrant the customers' funds.

The purpose of banking supervision as previously discussed is to protect customers, 
especially depositors. Legal protection for depositors philosophically lies on the principles of justice i.e., providing justice for depositors with safety. The legal correlation between banks and depositors is that banks are as money lender of public funds, so that with this capacity customers are as creditors of the banks. Reliance is the only motive for customers to save the money at the banks. Banks do not provide any guarantee for customers, or the warranty given by the banks is merely based on the general law. In the general warranty, the law provides legal protections for all creditors at the same level or based on principle of "paritas creditorum" where the payment process or debt settlement is done equally (ponds-ponds gewijs). Thus, the creditors run as competing creditors that compete in the accounts receivables fulfillment, unless they are given a preference position (droit de preference) (Sofyan, 1981). The right to give priority to creditors due to a balanced position does not provide certainty of warranty for the credits return. Creditors do not know that other creditors may come in the future. The more creditors from the debtors, the smaller opportunity of credit returns if the creditors are in the insolvency (the inability to pay debts) (Ibrahim, 2004). When the fund return is settled trough liquidity mechanism, the creditor's position is only as a competing creditor that will compete with other creditors for the fund returns. It is stated in article 54 Law Number 24 of 2004 on Indonesia Deposit Insurance Corporation that put creditors toward the payment of bank liquidation on the sixth position after banks' liabilities toward other creditors (Ratnaningsih, 2008). Therefore, legal protection for creditors is required through mechanism of banking supervision and legislation to maintain good operational that may increase public reliance.

\subsection{Banking Supervision Model of Otoritas Jasa Keuangan}

The idea of Otoritas Jasa Keuangan establishment emerges from compromises to avoid impasse on discussion of Law of Bank Indonesia by Indonesian Legislative Assembly. At the beginning of B. J. Habibie's presidential leadership, the government proposed draft of a law on Bank Indonesia that give independence for Bank Indonesia, and issued functions of banking supervision of Bank Indonesia. The idea of supervision division from the central bank comes from Helmut Sclesinger, the former Governor of Bundesbank (Central Bank of Germany) that acts as a consultant, considering the pattern of Germany's Central Bank that does not supervise banks, at the law drafting (later become Law Number 23 of 1999 on Bank Indonesia). At the time the draft of law is proposed, some rejections emerged from the Indonesian Legislative Assembly and Bank Indonesia, as compromises that the institution replacing Bank Indonesia in supervising banks is also obliged to supervise other financial institutions. It is aimed to close the fact that the divisions of supervision detract the authority of Central Bank. The establishment of Otoritas Jasa Keuangan is a mandate of article 34 Law Number 23 of 1999 and Law Number 3 of 2004 on Amendment of Law Number 23 of 1999 on Bank Indonesia.

After Otoritas Jasa Keuagan is established, there are 2 (two) institutions that have the authority of banking supervisions. OJK has the authority of microprudential banking supervisions and Bank Indonesia has the authority of macroprudential banking supervisions. The division of authority between OJK and BI has no clear limitations. The explanation of article 7 of Law Number 21 of 2011 on Otoritas Jasa Keuangan stated that "Supervision of institutions, reliability, thoughtfulness, and banks control belongs to microprudential supervision under the authority of OJK. The scope of macroprudential supervision that is not regulated in this article is the authority of Bank Indonesia......"

The divisions of authority of microprudential banking supervision from Bank Indonesia to Otoritas Jasa Keuangan has legal implication on the duty and authority of $\mathrm{BI}$ as the Central Bank regarding to the function of $\mathrm{BI}$ as a lender of last resort.

The Article 23 D of the 1994 Constitution of the Republic of Indonesia which determines that "The state has a Central Bank whose structure, position and authority, responsibilities and independence are regulated by the Law." Based on the Law Number 7 of 1992 on Banking as amended with the Law Number 10 of 1998 Chapter I General provision of article 1 section 20, which stated that Bank Indonesia is the Central Bank of Indonesia as enacted in the existing law. Besides, the status of Bank Indonesia is regulated in the Law Number 3 of 2004 on the amendment of Constitution of Indonesia Number 23 of 1999 on Bank Indonesia in the article 4 section 1 which 
stated that "Bank Indonesia is the Central Bank of the Republic of Indonesia." Based on the explanation in article 4 section 1, the Central Bank is a state institution that has the authority to issues legal payment instrument, to formulate and perform monetary policies, to regulate and maintain the smoothness of payment system, to regulate and supervise banking and to run the functions as the lender of the last resort. The Law Number 23 of 1999 on Bank Indonesia as amended with the Law Number 3 of 2004 provides a clear legal foundation for the independence of Bank Indonesia. The institutional status and position of Bank Indonesia as an independent institution and which has the autonomy is explicitly mentioned in the article 4 section 2 of the Law Number 23 of 1999 on Bank Indonesia as amended with the Law Number 3 of 2004 which stated that "Bank Indonesia is an independent state institution that in carrying out its duties and authorities are free from the interference of the government and other parties, except by the law clearly stated in this law." Based on the law, Bank Indonesia is the independent "state institution" in the monetary field. Regarding to the status of Bank Indonesia as an independent institution in the article 9 Law Number 23 of 1999 on Bank Indonesia as amended with the Law Number 3 of 2004 strictly prohibits other parties, including government, to interfere all duties of Bank Indonesia as monetary authority. If interference of other parties found, Bank Indonesia is obliged to refuse or to ignore. Violation of this rule will cause sanctions to all parties as stated in the article 67 with great fining and punishment. The independent status of Bank Indonesia is a warranty for Bank Indonesia, at least at the legal aspect, to effectively run the duties. It also guarantees the legal certainty of institutional status of Bank Indonesia (Rahardja, 2001). The authority of $\mathrm{BI}$ to regulate and supervise banks which is finally undertaken by OJK, basically damages the independence of $\mathrm{BI}$ as a Central Bank. Besides, the implementation of the Law of OJK does not go along with the revision of the Law of $\mathrm{BI}$ and Law of banking regarding the institutions that have authority to regulate and supervise banking, indicating conflict of norms that cause the absence of legal certainty for institutions that have the authority of banking supervisions.

Otoritas Jasa Keuangan is an independent state institution or state auxiliary bodies whose establishment, status and position are based on the Law Number 21 of 2011 on Otoritas Jasa Kuangan (UU OJK), Government Gazette of the Republic of Indonesia of 2011 Number 111, Additional Government Gazette 5253. Based on the history of the establishment, OJK is actually including in one of Letter of Intent (LOI) points between government and IMF as one requirement for government loans in the economic crisis in 1997-1998 with objections from many parties, those are Indonesian Legislative Assembly, government, and Bank Indonesia that almost do not have any power to refuse IMF's provisions, including the establishment of OJK. The establishment of OJK is motivated by disappointment on $\mathrm{BI}$ in conducting banking supervisions in Indonesia, it was the monetary crisis in 1997 resulting 16 banks are liquidated, the misuse of Bank Indonesia Liquidity Assistance to help damaging banks in 1997 causes the case of Century Bank in 2008. These cases show that $\mathrm{BI}$ as the regulator and supervisor of banking is fail to run the duties that finally motivate government to establish a new integrated supervision system namely Otoritas Jasa Keuangan (OJK). The establishment of OJK is a mandate of the article 34 of the Law of Bank Indonesia. Besides, the development of financial conglomeration may facilitate one main enterprise to have several institutions at different financial institutions. It causes interrelation of one institution and another so as the risks. Based on the consideration, the supervision should be comprehensive, thus it will also enable comprehensive risk analysis. Beside the development of conglomeration, regulatory arbitrage also influences. Regulatory arbitrage is done by financial institutions, in which the product is supervised by authority with more flexible regulations. It is the misuse that occurs when financial sector supervision is done partially. Financial institutions tend to choose investment on instruments supervised by supervisory institutions which implement a non-binding regulation.

Normatively, Otoritas Jasa keuangan is independent, but the existence of ex-officio Bank Indonesia and ex-officio of the Ministry of Finance in the structure of Commissioner Board of OJK doubt the independence status of OJK. The Law of OJK explains that institutionally, OJK does not belong to government's authority. But it makes elements of government possible to exist, because OJK is an authority of financial sector that strongly relates to other authorities, those are fiscal and monetary authorities. Therefore, this institution involves the representation of both authorities in an ex-officio manner. The existence of ex-officio is needed to maintain national interest in the global 
competition and international agreement, and the need of coordination and information exchange in maintaining financial system stability. To obtain good coordination, cooperation, and harmonization of policies, OJK shall be part of government system which interacts well with other state and government institutions in achieving the goals and ideals of Indonesian independence. Regarding to this explanation, independence of OJK is not absolute. Many experts in banking sectors recognize the representation of government on the structure of OJK. The argument is that independence of financial sector supervision is different from central bank independence in maintaining monetary policies, which means in the financial sector, government is politically responsible to keep the financial system stability, because the failure of one or more financial institutions, markets or infrastructures have strong implications on the public's economy. Therefore, the state should have controlling mechanism such as delegating government's representative who is actively participate in the management of the supervisor authority (Kusbiantoro, 2013).

Regarding the divisions of microprudential and macroprudential, Deputy of Banking Industry Management Commissioner of OJK, Lucky FA Hadibrata, stated that there is no certain clearness on the division of macroprudential and microprudential borders on banking supervision, it is being discussed in Basel and Washington DC to find out the dividing lines. Each country has different comprehension in performing macroprudential and microprudential duties (Sulaiman, 2014). Pasaribu also stated that the term of macroprudential and microprudential has not been defined and not recognized in the legal products both the Law of $\mathrm{BI}$ and the Law of OJK. Based on Basel Committee for Banking Supervision (2011), the main target of banking supervision is to boost safety and fairness of bank in the banking system. In the same jurisdiction, bank supervisor (microprudential) explicitly responsible for financial stability, a responsibility which is implicitly and explicitly part of the Central Bank's mandate. Both individual and systematical risks are interrelated. Instability of financial system also comes from the instability of financial industry actors. Individual health of financial institution will build financial system stability. Financial system stability also contributes to create good and fair condition of individual financial institution. Division of microprudential and macroprudential potentially affects overlapping because both microprudential and macroprudential have the same objects i.e., the financial institution (Pasaribu, 2015).

Based on the above explanation, there are some cases that should be considered in order that the supervision of banking in Indonesia meets the principles of justice, legal certainty, and expediency. First, the division of banking supervision from $\mathrm{BI}$ to OJK potentially complicates $\mathrm{BI}$ in running the duties with some juridical facts that should be considered. To determine and perform monetary policies, Bank Indonesia should determine the flow of inflations by considering development and prospect of macro economy especially the flow of prices. To obtain the target of inflation rates, $\mathrm{BI}$ establishes the targets of monetary and liquidity of the economy. Monetary control is performed with various instruments, such as Open Market Operation, determination of discount rates, minimum liability reserves, credit disposition or payment. In establishing and performing monetary policies, BI plays as a lender of the last resort that enables BI to help bank's liquidity with short-term difficulties. The grant of funds made by the bank as the lender of the last resort is valid for 90 days and the use should be guaranteed with high quality important documents as stated in article 11 of UUBI because it may causes difficulties if $\mathrm{BI}$ does not regulate and supervise the banks directly. Seconds the division of banking supervision cause ineffective monetary policies. To establish monetary policies, BI needs primary data that can be directly accessed from actors of industry. If it is separated and $\mathrm{BI}$ only obtains secondary data from OJK or Perbanas (national banking), Bank Central cannot make fast and efficient policies when crisis happens due to the absence of the primary data. In obtaining mandatory reserve, Bank Indonesia should understand liquidity access of markets, as well as open market operation that becomes the instrument of Bank Indonesia in implementing monetary policies to draw liquidity should be supported by accurate data, thus BI should understand daily condition of the banks (Satriyo, 2015)

The authority of Bank Indonesia as a lender of the last resort is strongly related to the public interest especially depositors. To achieve the principle of justice, giving the authority of banking supervision back to Bank Indonesia is a precise policy. However, the importance of OJK in Indonesia is undeniable. OJK should be able to access data and information system directly which is related to banking supervision performed by Bank Indonesia. It means that, data or information 
system of banking supervision also related to OJK, thus fairness and safety of the bank is warranted. Besides, it should be followed by monthly coordination between $\mathrm{BI}$ and OJK in every district and is not limited to the financial system stability forum held by the central every three months, so that both institutions are able to synergize in regulating and supervising banks to always be in good conditions for the sake of legal certainty and public justice.

Article 64 of the Law of OJK section 1 stated that: "since the change of function, duty and authority as in article 55 that officials and/ employees of Badan Pengawasan Pasar ModalLembaga Keuangan (Indonesian Market and Financial Institution Supervisory Agency), and official, and/ employees of Bank Indonesia that perform the functions, duties, and authorities on regulating and supervising banking sectors, as referred to in article 63 section 4 is shifted to be performed by Otoritas Jasa Keuangan. The provision in this article is interesting to be examined because the establishment of OJK is caused by disappointment toward $\mathrm{BI}$ as a banking supervisor. It also shows unreadiness of OJK's human resources to supervise banking, thus recruiting the employee of Bank Indonesia to work in OJK. This fact institutionally indicates that the shifts of banking supervision authority from $\mathrm{BI}$ to $\mathrm{OJK}$, the employees recruited are the same people when the authority was given to BI. Nindyo Pramono opines that the banking crisis is caused by the insufficient function of Bank Indonesia, substantially the fundamental factor lies on the incredible, unqualified, and dishonest human resources (Pramono, 2010). Considering this condition, the shifting of banking supervision authority from $\mathrm{BI}$ to OJK does not fulfill the principle of expediency. Properly, OJK recruited more credible human resources, indeed it is not easy to do. Therefore, banking supervision certainly should be the authority of Bank Indonesia to support its duty in maintaining the stability of the value of Rupiah, yet the supervisory method should be strengthen out with the existence of information system that can be accessed by Otoritas Jasa Keuangan as the regulator and supervisor of integrated financial service sectors in Indonesia.

\section{Conclusion}

1. The philosophical meaning of Banking Supervision is as a legal protection for depositors by providing reliability and safety that the banks where the funds deposited are in good and fair conditions under the institutions that have the authority to supervise. Public reliance toward banking is significant for the continuity of the institution.

2. The existence of Otoritas Jasa Keungan cause legal implications on the division of microprudential and macroprudential of banking supervision where both are still interrelated. Microprudential division which previously belongs to Bank Indonesis authority may potentially complicate Bank Indonesia in running its duties as the Central Bank and as the lender of the last resort. Therefore, synergy between Otoritas Jasa Keuangan and Bank Indonesia by giving banking supervision back to Bank Indonesia by the existence of data sharing that can be accessed by Otoritas Jasa Keuangan, thus the establishment of OJK as supervisor of integrated financial service sectors to avoid financial conglomeration and arbitration of regulation can be implemented in achieving justice, legal certainty, and expediency for depositors related to banking supervision that is to maintain public reliance toward banking institutions.

\section{Suggestions}

Considering the efforts of resolving crisis, the Law Number 9 of 2016 on Prevention and Resolution of Financial System Crisis has been issued. This article does not elaborate the correlation of the Law and the division of microprudential supervision by Otoritas Jasa Keuangan and macroprudential supervision by Bank Indonesia. It can be further investigated in the future.

\section{Acknowledgement}

Highest gratitude and thanks sent to Ministry of Research, Technology and Higher Education who has provided research grants for doctoral dissertation that is implemented in this article, Budget 
Realization of Directorate General for Research and Development with SP DIPA -042.06.1.401516 / 2017.

\section{References}

Amiruddin, ett.al., (2016). Pengantar Metode Penelitian Hukum [Introduction to Law Research Method] Jakarta: Raja Grafindo Persada.

Brugink JJ translated by Sidharta A. (1999). Refleksi Tentang Hukum [The Reflection of Law]. Bandung: Citra Aditya Bhakti.

Cranston R. (1997). Principles Of Banking Law. Oxford: Clarendon Press

Dewatripont M and Tirole. (1994). The Prudential Regulation Bank. London England: The Mitt Press Cambridge

Dewantara R. (2011). Tinjauan Yuridis Pengalihan Pengawasan Perbankan dari Bank Sentral Kepada Otoritas Jasa Keuangan [The Juridical Review of The Banking Supervision Shifting from Central Bank to Financial Service Authority]. Risalah Hukum Fakultas Hukum Unmul. ISSN 021-969X Volume 7 No.2, December 2011 page 177

Djumhana M. (2003). Hukum Perbankan di Indonesia [Law of Banking in Indonesia]. Bandung: Citra Aditya Bakti

Hasanah U. (2017). Hukum Perbankan [Law of Banking] Malang Jawa Timur: Setara Press

Ibrahim J. (2005). Teori dan Metode Penelitian Hukum Normatif [The Theory and Method of Normative Law Research]. (1st ed.). Malang: Bayu Media Publishing.

Ibrahim J. (2004). Cross Default and Cross Collateral Sebagai Upaya Penyelesaian Kredit Bermasalah [Cross default \& Cross Collateral as the Solution of Troubled Credit]. Jakarta: Reflika Aditama.

Ismail N.H. (2007). Perkembangan Hukum Pertanahan [The Development of Land Law]. Jogjakarta: HUMA and Magister of Law UGM.

Isnaeni. (2016). Pijar Pendar Hukum Perdata [Incandescent of Civil Law]. Surabaya: Revka Petra Media.

Kaufman G. (1995). Bank failures, Systemic Risk and Bank Regulation. The Cato Journal. Volume 16. No. 1 page 2 .

Kusbiantoro F. (2013). Independensi Otoritas Jasa Keuangan Dalam Pengawasan Kegiatan Di Sektor Jasa Kauangan [Independency of Otoritas Jasa Keuangan in the Supervision of Financial Service Sector]. Jakarta, Thesis of Master Degree Program Majoring Economic Law of University of Indonesia.

Marzuki P.M. (2016). Penelitian Hukum [The Research of Law]. (Revised ed.). Jakarta: Prenada Media Group.

Prasetya T and Barkatullah A.H. (2012). Filsafat, Teori, IImu Hukum (Pemikiran Menuju Masyarakat yang Berkeadilan dan Bermartabat) [Philosophy, Theory, Law Science (Thoughts Towards Justice and Dignified Society]. Jakarta: Raja Grafindo Persada.

Pasaribu G.W. (2015). Gagasan Sinergi Makro dan Makroprudensial [The Idea of Macro and Microprudential Synergy]. Retrieved from www.solopos.com. Last Accessed on 14 August 2015.

Pardede M. (2001). Efektifitas Pengawasan Perbankan (Basle Committee on Banking Supervision) dalam Perbankan Nasional Indonesia [Effectivity of Banking Supervision (Basle Committee on Banking Supervision) in the National Banking of Indonesia]. Journal of Business Law. Volume 15. Page 56.

Pramono N. (2010, September). The Implication of Law Foundation in the System of State Administration to Reach the Goal and the Task Implementation of Bank Indonesia as The Bank Central Republic of Indonesia. The Magazine of Banking Law and Central Banking. Volume 8 Number 3. Page 7

Rahardja. M.D. (2001). Independensi Bank Indonesia dalam Kemelut Politik [Independency of Bank Indonesia under Political Issues]. Jakarta: Pustaka Cidesindo

Ratnaningsih. (2008). Perlindungan Hukum Terhadap Nasabah Penyimpan Dana oleh Lembaga Penjamin Simpanan [The Legal Protection of Depositors by Indonesia Deposit Insurance Corporation]. Jember. Tesis of Master Degree Program Majoring Law.

Satriyo, A.N. (2015). Mengantisipasi Krisis Moneter [Anticipating the Monetary Crisis]. Retrieved from www.indonesiareview.com. Last Accessed on July 30, 2015.

Sulaiman, F. (2014). BI dan OJK Akui Sulit Pisahkan Makro dan Mikro Prudensial [BI and OJK stated the difficulty to separate Macro and Micro Prudential]. Retrieved from www.wartaekonomi. co.id. Last Accessed on August 25, 2014.

Sugiyono, F.X., and Ascarya. (2003). Kelembagaan Bank Indonesia [The Institution of Bank Indonesia]. Jakarta: Pusat Pendidikan dan Studi Kebanksentralan Bank Indonesia.

Sofyan, S. (1981). Hukum Benda [The Property Law]. Yogyakarta: Liberty

Wijoyo, N.A. (2015). Referensi Resiko Sistematik Perbankan [The Reference of Banking Systemic Risk]. Jakarta: Universitas Indonesia Press. Page 8. 